
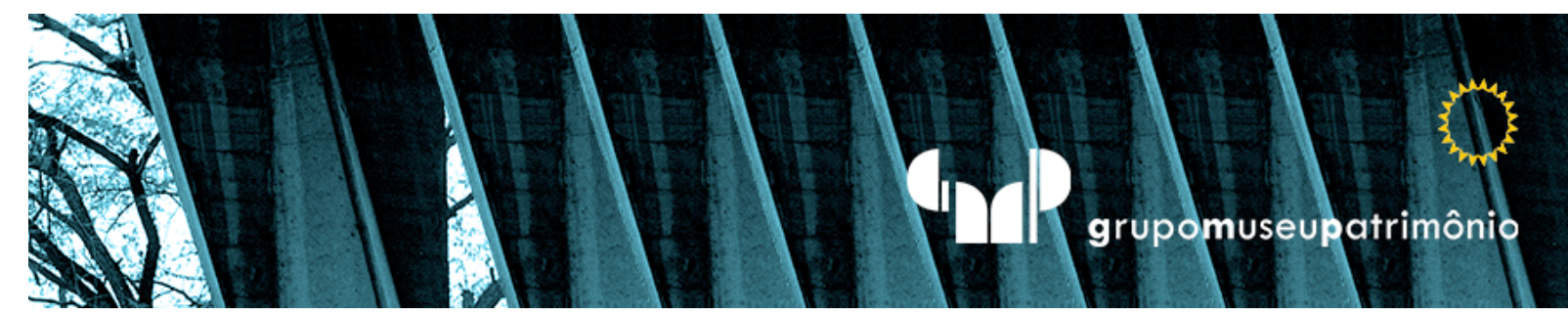

\title{
Experiência e representação: por uma fenomenologia das imagens em Noite e neblina (1955), de Alain Resnais ${ }^{1}$
}

\author{
Experiencia y representación: por una \\ fenomenología de las imágenes en Noche \\ y niebla (1955), de Alain Resnais \\ Experience and representation: for an \\ image phenomenology in Night and fog \\ (1955), by Alain Resnais
}

Priscyla Gomes

Universidade de São Paulo, São Paulo, Brasil. priscylagomes@usp.br

Felipe Kaizer Universidade Estadual do Rio de Janeiro, Rio de Janeiro, Brasil. fk@felipekaizer.com

\footnotetext{
${ }^{1}$ O presente artigo é fruto da colaboração entre Priscyla Gomes e Felipe Kaizer em pesquisas e projetos desde 2015. As primeiras pesquisas acerca do método fenomenológico ocorreram como desdobramento de um trabalho curatorial e a publicação de textos conjuntos acerca da produção e do processo criativo de alguns artistas. Deste prenúncio, seguiram outras curadorias conjuntas, bem como a realização de artigos e cursos livres acerca de temas comuns e da complementariedade das pesquisas acadêmicas desenvolvidas.
} 


\section{Resumo}

O presente artigo parte do filme Nuit et broulliard (1955), produzido pelo cineasta francês Alain Resnais, para discutir a potência das imagens e os limites da representação de fatos históricos tidos como crimes à humanidade. Propõe-se uma leitura da abordagem de Resnais, considerando os princípios da fenomenologia e a crise da experiência no mundo moderno e suas implicações na contemporaneidade.

Palavras-Chave: Cinema. Imagem. Fenomenologia. Experiência. Política.

\section{Resumen}

El presente artículo parte del film Nuit et broulliard (1955), producido por el cineasta francés Alain Resnais, para discutir la potencia de las imágenes y los límites de la representación de hechos históricos considerados crímenes contra la humanidad. Se propone una lectura sobre el enfoque de Resnais, considerando los principios de la fenomenología y la crisis de la experiencia en el mundo moderno y sus implicaciones en la contemporaneidad.

Palabras-Clave: Cine. Imagen. Fenomenología. Experiencia. Política.

\section{Abstract}

The present article is in reference to the movie Nuit et broulliard (1955), a production by the french filmmaker Alain Resnais, to discuss the power of images and the boundaries of representing historical facts acknowledged as crimes against humanity. A reading of Resnais' approach is proposed, considering the principles of phenomenology and the crisis of experiences in the modern world, as well as its implications in contemporaneity.

Keywords: Cinema. Image. Phenomenology. Experience. Politics. 


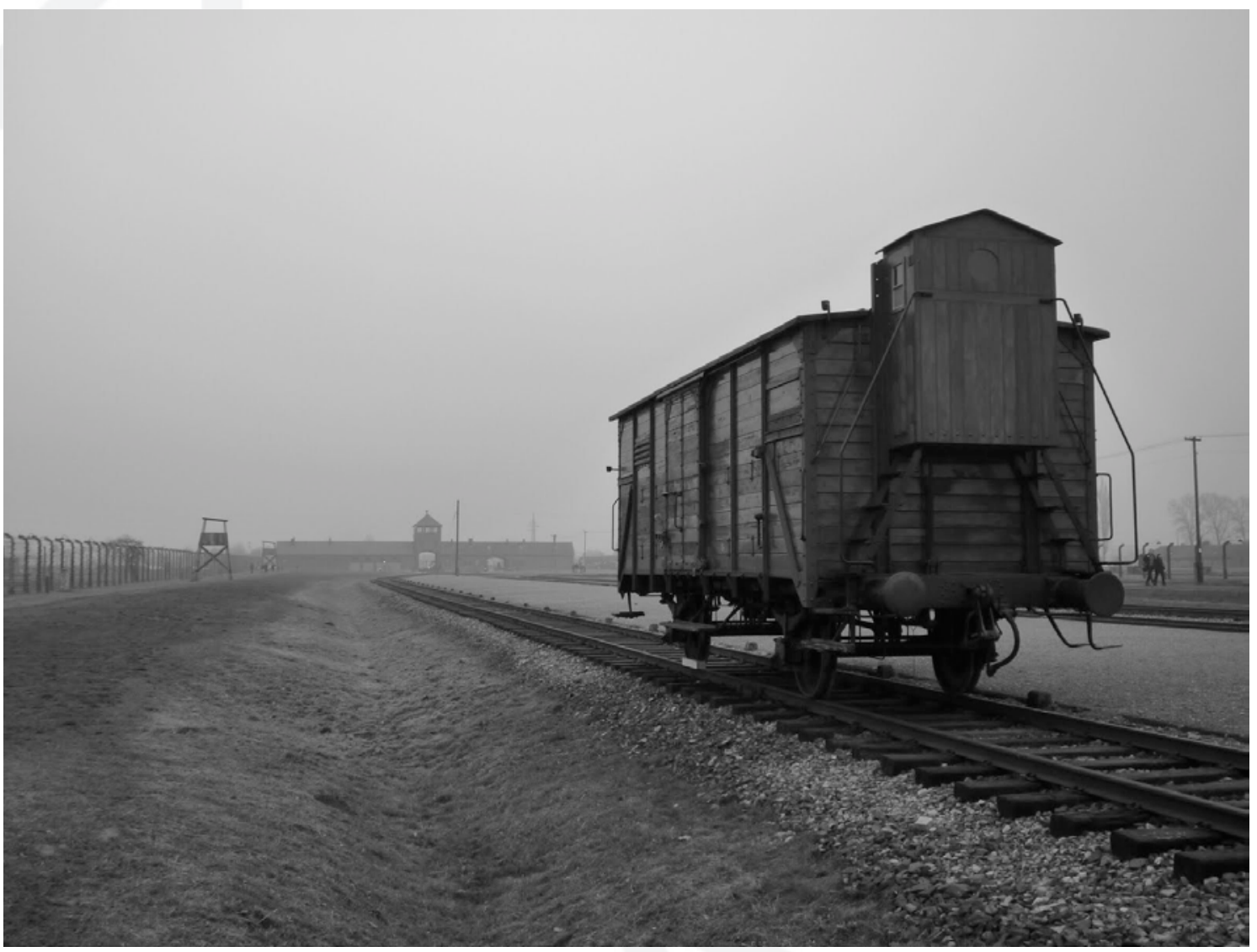

Figura 1: Stills do filme. Fonte: Nuit et brouillard (Noite e neblina), 1955.

Em travellings lentos, a câmera não se mexe senão nos cenários vazios, reais e vivos - ligeira agitação dos tufos de erva - mas vazios de qualquer ser, e de uma realidade quase irreal à força de pertencer a um mundo que,

para mais, é o de uma improvável, impossível sobrevivência. A câmera parece deslocar-se em vão, sem efeitos reais, desapossada do drama, do espetáculo que estes movimentos parecem acompanhar, mas que não são senão os de fantasmas invisíveis. Tudo está vazio, imóvel e silencioso; fotografias seriam suficientes. Mas, precisamente, a câmera move-se, ela é a única a mover-se, ela é a única vida, não há nada a filmar, ninguém, só resta o cinema, não há nada de humano e de vivo a não ser o cinema, diante de alguns vestígios insignificantes, derrisórios, e é este deserto que a câmera percorre, é sobre ele que ela inscreve o rastro suplementar, rapidamente apagado, dos seus trajetos muito simples.

(FLEISCHER, 1998, p. 53, tradução nossa) 
$\dot{\mathrm{A}}$ primeira vista, uma cena prosaica: trilhos abandonados com caminhos interrompidos, um edifício aparentemente sem uso, uma vegetação que cresce desordenadamente. Mais à frente, um descampado. Não há indícios de vida humana. Os terrenos delimitados por extensas linhas de arame farpado são as mais claras referências ao controle e à não transposição. No tempo presente, apenas a câmera passeia maquinalmente por aquilo que fora um centro de extermínio em massa. É uma voz off, já nos primeiros minutos, que nos confirma a fatídica natureza desses espaços.
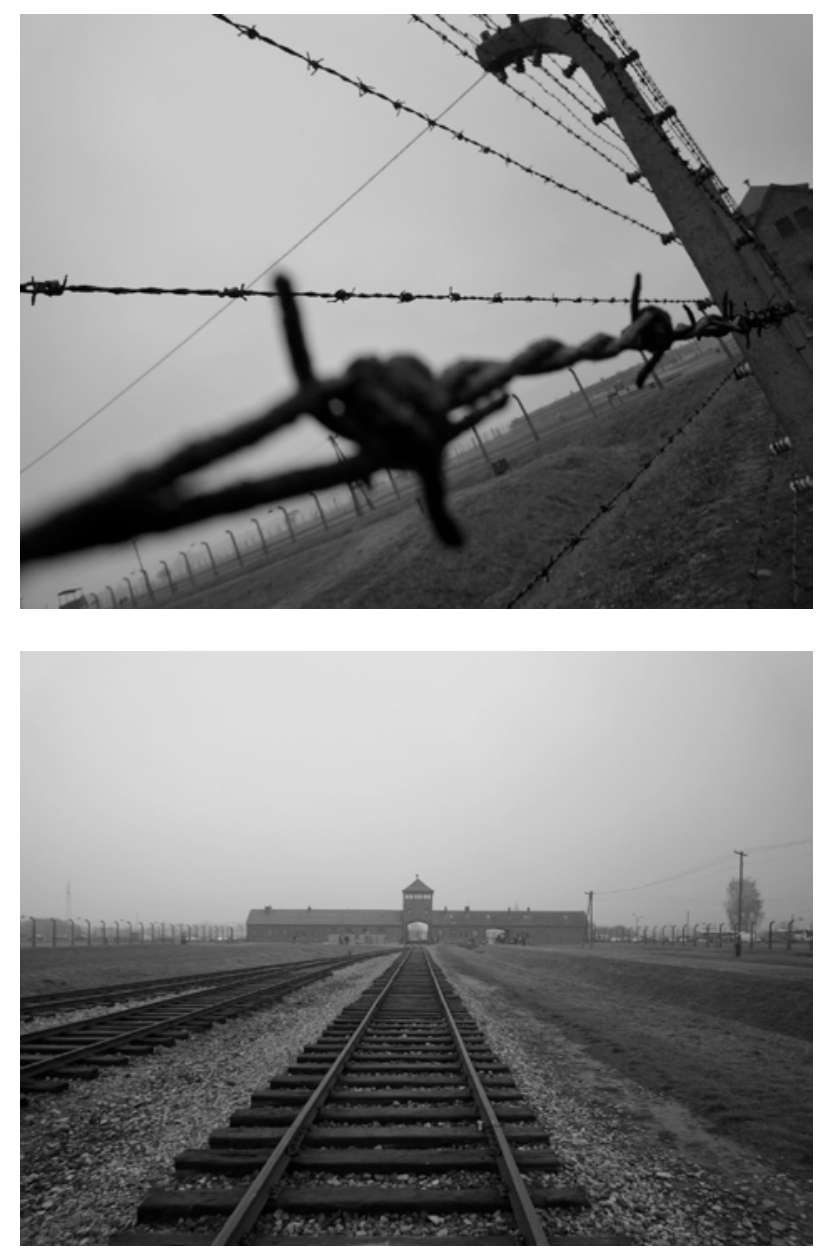

Figuras 2 e 3: Stills do filme. Fonte: Nuit et brouillard (Noite e neblina), 1955. 
O texto redigido pelo poeta Jean Cayrol para o filme Nuit et brouillard (Noite e neblina) do cineasta francês Alain Resnais é o fio condutor da narrativa que, rapidamente, nos transpõe do percurso por uma paisagem campesina para um desvelar austero da arquitetura e da história dos campos de concentração. Lançada em 1955, a produção é fruto de um convite do Comitê de História da Segunda Guerra Mundial ao diretor, disponibilizando um vasto material de documentação do cotidiano dos campos. A esse material Resnais acrescenta planos captados em Auschwitz e Majdanek, na Polônia, no outono desse mesmo ano. A natureza distinta dessas imagens marca o ritmo e a tensão presentes: Resnais combina imagens de arquivo de corpos, com travellings meticulosos das instalações abandonadas. O filme não recria o contexto, apenas mostra as evidências restantes, a cores. É uma maneira de se circundar a questão, de entrevê-la, sem explicá-la.

A escolha da montagem do material documental, atrelada a excertos contemporâneos das locações, possui claras diretrizes cinematográficas. Resnais associa imagem e violência tendo como imperativo não a compreensão de Auschwitz como um fenômeno, tampouco uma tentativa de reconstituição imagética desses fatos; a proposta é uma clara suspensão temporal dos atos, com a conviç̧ão da impossibilidade de mensurar o extermínio.

Com a montagem e o sequenciamento de imagens de extrema frieza, Nuit et brouillard impõe-nos uma série de questionamentos políticos, estéticos e históricos. Em primeiro lugar, há um debate propriamente cinematográfico: é possível representar o irrepresentável? Qual imagem faria jus ao ocorrido nesses campos? Que narrativa poderia relatar tais feitos sem se assemelhar a uma fetichização inapropriada do horror? 


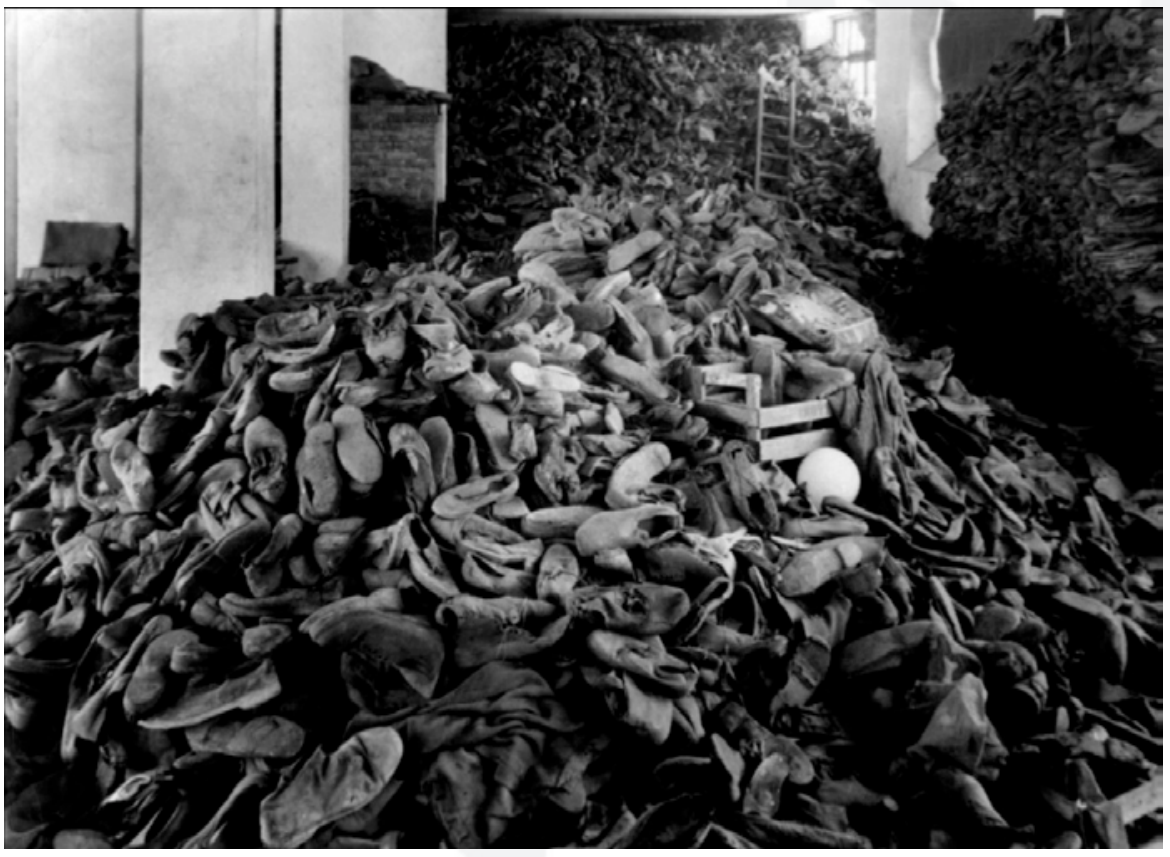

Figura 4: Still do filme. Fonte: Nuit et brouillard (Noite e neblina), 1955.

O cinema do pós-guerra toma para si a problemática e as implicações de abordar esses relatos e de questionar o papel da narrativa na produção e veiculação de imagens desses episódios traumáticos. O cinema moderno, a fim de distanciar-se do modelo hollywoodiano calcado nas possibilidades da interpretação e ficcionalização do tema, abdica de uma representação mimética. Sua proposta é dar conta de sua condição de artifício. O imperativo da escolha é ético e determina um modo de fazer cinema.

Nuit et brouillard explicita uma postura fundamental ante o inimaginável tornado realidade histórica: a de conferir ao cinema o estatuto de testemunho. Jean Cayrol, na condição de sobrevivente de Mauthausen-Gusen, imprime ao texto esse caráter de testigo. Sua escolha teria sido determinante a Resnais para o aceite da elaboração da película: a narração ganhava uma dimensão de experiência vivida que reforça o caráter do filme como um documento.

Embora a potência do texto de Cayrol trouxesse claras passagens que remetem ao trauma a indiscernibilidade do sujeito diante de tantos desmandos, seu 
depoimento explicita a iminência do esquecimento pela história de crimes tão hediondos: "O sangue coagulou, a boca silenciou [...] a corrente elétrica não passa mais pelos fios; não há outros passos além dos nossos". Em suma, resta pouco para ver. Toda vida e atividade cessaram sem deixar rastros. "Enquanto vos falo agora, a água fria dos pântanos e das ruínas preenche o buraco das valas comuns, uma água fria e opaca como a nossa má memória."

A narrativa de Cayrol se divide em três partes: a primeira remete ao advento nazista, à vitória alemã, à captura e morte das primeiras vítimas; a segunda narra a vida nos campos, os trabalhos forçados, as humilhações sofridas; e a terceira aborda a empreitada desumana de extermínio dos deportados, a engenharia refinada dessas mortes. Embora extremamente vinculada à sua vivência pessoal no campo, a narrativa se descola para uma abordagem em terceira pessoa, uma saída que só reforça o caráter das imagens que Resnais conjuga e produz (GOMES, 2016).

O testemunho da película guarda diversas relações entre o estético e o político no que tange a passagem do tempo e o estatuto das nossas experiências contemporâneas. Na obra documental de Resnais, representada por uma série de curtas-metragens realizados ao longo da década de 1950, já se fazia evidente o enfoque do cineasta ao estudo das relações entre o tempo e a memória. Ao diretor cabia questões primordiais: como abordar o inimaginável, de modo a não deixar que passe ao esquecimento? E se, como trauma, ele não passa, de que forma se esconde doravante por detrás de uma certa banalidade ${ }^{2}$ ?

\footnotetext{
${ }^{2}$ Pela expressão "banalidade do mal", presente no subtítulo do livro sobre o julgamento de Adolf Eichmann, lançado em 1963, Hannah Arendt foi privada e publicamente atacada (ARENDT, 1999). A expressão, no entanto, nada tem de banal ela mesma. Obviamente, Arendt não estava fazendo pouco caso do extermínio dos judeus, mas tentando iluminar um novo ponto sobre uma velha questão: qual a natureza do mal? Ela chegou à conclusão de que não se tratava de uma manifestação do mal radical, mas de um sujeito banal, intelectualmente limitado, mas ainda assim (e talvez justamente por isso) capaz de atrocidades. Arendt relacionou a ausência de pensamento e a incapacidade de juízo de Eichmann aos seus atos de suprema inumanidade. A banalidade do mal nomearia assim não uma condição de indivíduos especiais, mas uma ameaça à espreita de todos nós.
} 


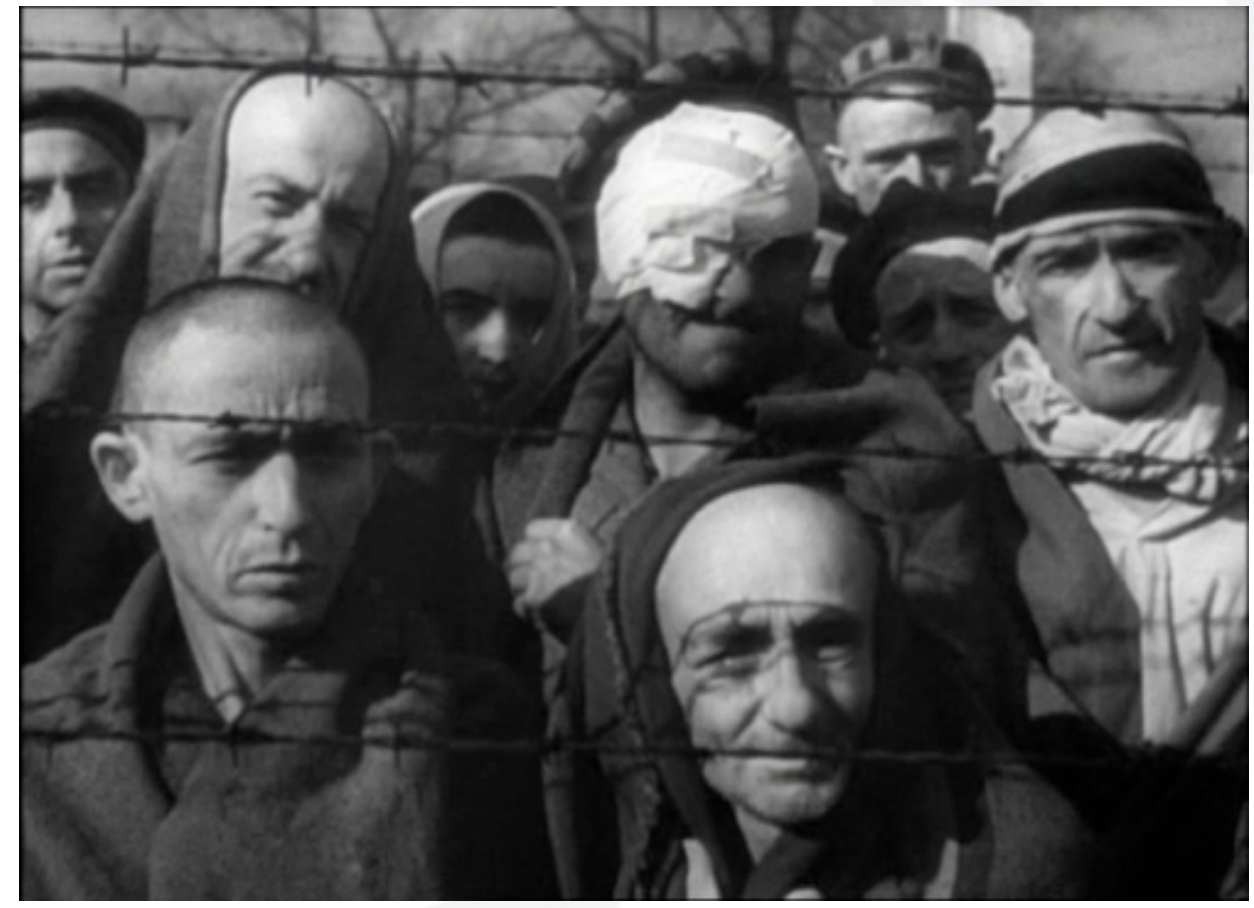

Figura 5: Still do filme. Fonte: Nuit et brouillard (Noite e Neblina), 1955.

Para conectar a contemporaneidade com a experiência dos genocídios na Segunda Guerra Mundial são necessárias algumas balizas. A primeira delas passa pela trajetória histórica narrada pelas mais diversas fontes que buscam dar conta desses fatos, outra pela suposição de que exista uma conexão profunda entre o subjetivo e o social ${ }^{3}$, assumindo que eventos de tal ordem moldaram nossos modos de ser no presente.

E mais: há alguma conexão entre o massacre irrepresentável dos judeus e a atual banalização das nossas imagens? O objetivo aqui é aproximar-se de uma questão premente na nossa época: nossa maneira de olhar e de perceber o mundo ao redor, incluindo a arte, não é mais a mesma depois das duas guerras

\footnotetext{
${ }^{3}$ Em sua teoria, Sigmund Freud não se ateve a questões clínicas, mas especulou igualmente sobre a natureza do comportamento social. No que se refere à experiência da Primeira Guerra Mundial, Freud conceituou as neuroses de guerra, identificando lembranças desse tipo de trauma em ataques histéricos. Isso deu novos rumos à pesquisa freudiana, fazendo com que a ideia de trauma reaparecesse nos seus estudos entre 1915 e 1920 dissociada de objetos sexuais (FREUD, 1976).
} 
mundiais. Alguma coisa alterou-se profundamente, de forma que nossas produções hoje parecem-nos cada vez mais destituídas de sentido. A hipótese que norteia nossa investigação é de que esse esvaziamento do sentido da arte e das imagens é menos um atributo das coisas da arte e mais o sintoma de uma mudança na nossa maneira de experienciá-las.

\section{A EXPERIÊNCIA DA GUERRA TOTAL}

O mundo atual é nascido de um trauma. A Primeira Guerra Mundial representa a culminação de um longo século de crise social e política, iniciado com a Revolução Francesa. Ela constitui o divisor de águas para uma geração de intelectuais e artistas europeus, às voltas com um novo tipo de experiência do corpo, da psique e do espírito advinda da guerra total. "Total" porque não mais limitada aos ritos militares e às disputas estritamente políticas, mas voltada contra populações e grupos étnicos inteiros. A destruição em escala industrial marca um ponto sem retorno para a humanidade: os modos anteriores de vida e criação tornaram-se impossíveis. Por outro lado, tampouco continuou a ser possível o simples progresso, pois os desenvolvimentos científico e tecnológico pareciam ter chegado ao limite de uma contradição. Nessa situação de impasse, Walter Benjamin diagnosticou em 1933 uma crise:

[...] está claro que as ações da experiência estão em baixa, e isso numa geração que entre 1914 e 1918 viveu uma das mais terríveis experiências da história. Talvez isso não seja tão estranho como parece. $\mathrm{Na}$ época, já se podia notar que os combatentes tinham voltado silenciosos do campo de batalha. Mais pobres em experiências comunicáveis, e não mais ricos. Os livros de guerra que inundaram o mercado literário nos dez anos seguintes não continham experiências transmissíveis de boca em boca. Não, o fenômeno não é estranho. Porque nunca houve experiências mais radicalmente desmoralizadas que a experiência estratégica pela guerra de trincheiras, a experiência econômica pela inflação, a experiência do corpo pela fome, a experiência moral pelos governantes. Uma geração que ainda fora à escola num bonde puxado por cavalos viu-se abandonada, sem teto, numa paisagem diferente em tudo, exceto nas nuvens, e em cujo centro, num campo de forças de correntes e explosões destruidoras, estava o frágil e minúsculo corpo humano. 
Uma nova forma de miséria surgiu com esse monstruoso desenvolvimento da técnica, sobrepondo-se ao homem. (BENJAMIN, 1994, p. 114-115)

Trata-se da miséria da experiência em geral, isto é, não de experiências privadas, "mas de toda a humanidade" (Ibid., p. 115). Essa nova miséria surge em um contexto de desconexão entre os acontecimentos no início do século XX e a tradição cultural e política europeia. Tal desconexão, por sua vez, implica um esvaziamento do sentido do atual, "[p]ois qual o valor de todo o nosso patrimônio cultural, se a experiência não mais o vincula a nós?" (Ibid.). Isso manifesta-se na mudez dos soldados que passaram por experiências-limite - experiências capazes de lhes furtar a própria capacidade de experienciar como antes.

Há, portanto, uma conexão direta entre a experiência e o falar sobre a experiência, ou, mais exatamente, a sua narração. O tema reaparece no texto de 1936, "Der Erzähler: Betrachtungen zum Werk Nikolai Lesskows" ("O narrador: considerações sobre a obra de Nikolai Leskov"). Nele, Benjamin busca na obra de Leskov os traços do narrador que já "não está de fato presente entre nós" (Ibid., p. 197). Seu diagnóstico é novamente de crise: a arte do narrar estaria "em vias de extinção", considerando que a narração nada mais é que a "faculdade de intercambiar experiências" (Ibid., p. 197-198).

Nesse sentido, experiência é algo que se transmite. É a experiência do sujeito experimentado ou experiente, do sujeito que adquiriu uma sabedoria. A narração seria o modo específico de reprodução dessa sabedoria, que ligaria gerações. Mas esse não é o único sentido da experiência que se encontra em crise.

Nós herdamos a crise da experiência formulada por essa geração de pensadores, mas a ela adicionamos a nossa própria. Tal é a diferença de tempo histórico que é impossível ler os textos de Benjamin sem uma chave interpretativa conceitual e histórica: de que experiência e de que narrativa afinal ele fala? Seu mundo é o nosso mundo, sim, mas o nosso mundo não é o mesmo. Ao que tudo indica, há uma nova crise da experiência e da narrativa, cuja mudez não mais advém do choque da guerra. 
As gerações nascidas depois das grandes catástrofes do século XX têm dificuldade de conceber as experiências dos seus pais e avós. Isto é: justamente no momento histórico em que a experiência deixa de ser transmissível, cada nova geração parece mais apartada das anteriores e, consequentemente, do sentido do próprio tempo. Daí que, entre outras razões, nosso poder de imaginação (ou de fazer imagens) falhe diante de fenômenos como o Holocausto. E que os genocídios de hoje apareçam como imagens distantes no noticiário, com nenhum grau de realidade para os espectadores.

Importa a nós identificar o que ocorre com a banalização das imagens e com a nossa mudez, que não é mais exatamente a dos combatentes. Voltemos ao texto de Benjamin em busca de uma pista. Mesmo que não se trate mais do choque e do trauma da guerra, pode ser que nossa mudez remeta ainda a algum tipo de pobreza. Paradoxalmente, em um mundo cheio de ofertas de experiências, essa pobreza pode ser o resultado de um excesso, de um embotamento dos órgãos da experiência, por assim dizer. Nessas circunstâncias, a mudez coincide com uma espécie de falatório: reproduzimos frases e expressões prontas como reproduzimos o comportamento alheio daqueles que acreditamos terem tido uma experiência. Nossa fala torna-se, assim, banal ${ }^{4}$.

Se Benjamin está correto e há uma conexão entre experiência e narrativa, então é preciso voltar ao problema da experiência para entender a mudez e a banalização diante dos novos acontecimentos políticos, sociais e estéticos. A

\footnotetext{
${ }^{4}$ De maneira similar, em Sein und Zeit, Martin Heidegger utiliza o termo "falação" (Gerede) para se referir à fala própria do "impessoal" (das Man), isto é, a fala da pessoa despersonalizada pela "queda" da cotidianidade: "Na utilização dos meios de transporte público, no emprego dos meios de comunicação e notícias (jornal), cada um é como o outro. Este conviver dissolve inteiramente a própria presença no modo de ser dos "outros", e isso de tal maneira que os outros desaparecem ainda mais em sua possibilidade de diferença e expressão. $O$ impessoal desenvolve sua própria ditadura nesta falta de surpresa e de possibilidade de constatação. Assim nos divertimos e entretemos como impessoalmente se faz; lemos, vemos e julgamos sobre a literatura e a arte como impessoalmente se vê e julga; também nos retiramos das 'grandes multidões' como impessoalmente se retira; achamos 'revoltante' o que impessoalmente se considera revoltante. $\mathrm{O}$ impessoal, que não é nada determinado, mas que todos são, embora não como soma, prescreve o modo de ser da cotidianidade" (HEIDEGGER, 2006, p. 184).
} 
impressão inicial é de que à pobreza do falar corresponde uma pobreza do experienciar. Em outras palavras, não há o que falar porque nada há que tenha alimentado a fala. Tal crise da experiência, como um cerramento da capacidade de experienciar, é talvez tão calamitosa quanto a anterior, a crise da guerra total e do Holocausto ${ }^{5}$.

Essa pista remete-nos a uma certa tradição filosófica que pensou a experiência em geral. Trata-se de uma tradição formada por teorias do fenômeno. Na Era Moderna, alguns filósofos tentaram desenvolver uma maneira de falar do fenômeno sem recair no essencialismo da metafísica anterior. Immanuel Kant, com sua obra crítica, encontra-se no início desse processo, mas é a partir do século XX, com Edmund Husserl, que a fenomenologia surge como método preciso.

\section{O MÉTODO FENOMENOLÓGICO}

Como sugerimos, uma abordagem que devolva a experiência ao centro das nossas considerações passa por uma fenomenologia ou ciência dos fenômenos. E isso começa com o conceito de fenômeno.

Fenômeno, do grego phainómenon, é uma palavra filosófica para aquilo que aparece. Mais exatamente: aquilo que aparece à consciência. Etimologicamente, fenômeno liga-se aos termos phaínesthai (aparecer) e pháos (luz). A palavra alemã utilizada por Kant, Erscheinung, tem uma construção análoga: erscheinen (aparecer) de scheinen (brilhar). Em certo sentido, fenômeno é aquilo que reluz. Kant tratou do fenômeno em oposição ao númeno ou "a coisa em si". A razão dessa oposição era em parte lógica: "Como é que uma coisa tal qual ela é em si poderia ser submetida à nossa faculdade de conhecer e pautar-se por ela? Só o podem em princípios os objetos tais como eles aparecem, ou seja, os fenômenos" (DELEUZE, 2009, p.

\footnotetext{
${ }^{5}$ Como antevê Hannah Arendt: "Pode ser até que os verdadeiros transes do nosso tempo somente venham a assumir a sua forma autêntica - embora não necessariamente a mais cruel quando o totalitarismo pertencer ao passado" (ARENDT, 1989, p. 512).
} 
12-13). Isto é: se conhecêssemos a coisa tal como ela é, desconsideraríamos a nós mesmos enquanto sujeitos que a conhecem de determinado modo. Por outro lado, se estivermos cientes apenas do nosso conhecer, não teríamos acesso à coisa independente do nosso conhecer. Logo, "saber como possam ser as coisas em si mesmas [...], está completamente fora da nossa esfera de conhecimento" (KANT, 1983, p. 129). Resta-nos o conhecimento das coisas como elas nos aparecem.

Mas os fenômenos não são meramente produtos das nossas faculdades mentais nem simples ilusões. A rigor, eles "não são aparências, mas também não são produtos da nossa atividade" (DELEUZE, 2009, p. 23). A ilusão surge quando atribuímos ao númeno aquilo que é do fenômeno. Mais uma vez: fenômeno é simplesmente aquilo que aparece. A questão referente às causas da aparição é inteiramente outra.

Como disciplina filosófica, a fenomenologia nasceu na passagem para o século XX com os estudos epistemológicos de Edmund Husserl. Sua batalha era contra o psicologismo e o naturalismo que se pretendiam teorias do conhecimento e da lógica. Sua defesa era do a priori de toda ciência rigorosa, "absolutamente rigorosa". Sua busca era a mesma de toda filosofia antiga e moderna: o fundamento de todo o edifício do conhecimento, assentado sobre uma "ciência das ciências". Husserl, no entanto, estava ciente das crises do seu tempo. Sua vida e obra foram marcadas por uma luta constante com a herança intelectual e cultural da Europa.

Interessa-nos especificamente o princípio e o método da fenomenologia. De saída, segundo Husserl, a fenomenologia opõe-se à "tese do mundo" de caráter naturalista e psicologista, segundo a qual todos os fenômenos derivam simplesmente de uma suposta realidade física exterior (HUSSERL, 1980). Nesses termos, a própria consciência seria apenas um efeito do mundo no órgão cerebral, e toda ciência seria puramente empírica, sem fundamento transcendental (no sentido kantiano). Husserl defende, ao contrário, um retorno às "coisas mesmas", isto é, a como elas aparecem à consciência. Desse 
modo, ele reabre o problema da consciência nos seus próprios termos, resguardando uma diferença fundamental entre o físico e o mental.

Para tanto, Husserl inventa um novo método: ele reduz seu problema, retirando-o do domínio das chamadas ciências duras para constituí-lo como uma ciência pura. A redução fenomenológica é o meio pelo qual a realidade exterior como suposta fonte dos fenômenos é "posta entre parênteses", de modo que a investigação se concentre tão somente sobre os atos da consciência (HUSSERL, 1980, p. xi). Abandona-se a pergunta se as coisas como as percebemos existem realmente ou não. Desvencilha-se assim da física e da psicologia em nome de uma forma de descrição que possa recuperar a dignidade dos fenômenos. Husserl visa à recuperação do domínio próprio da filosofia, sem abrir mão das essências, mas as redefinindo segundo o novo método: compreendemos então as essências quando nos dirigimos diretamente às aparências.

O caminhar da fenomenologia dá-se então por suspensão - suspensão das certezas, das causas, da distinção entre sujeito e objeto. Trata-se de um "método da ausência de solo", pois a experiência com as coisas mesmas "sempre precisa criar primeiramente a cada vez para si mesma o seu solo" (GADAMER, 2012, p. 177). Assim, o fenomenólogo ajusta-se à coisa da qual quer capturar a essência, e, nesse sentido, emprega uma linguagem própria, que tem de ser desenvolvida a cada ocasião. Em certo sentido, ele reinaugura a linguagem de modo a revelar aquilo que aparece à sua consciência. E isso oferece mais uma pista de como a experiência e narrativa se copertencem: para que a experiência possa ser intercambiada, como afirma Benjamin, é preciso criar uma maneira de falar sobre ela como que pela primeira vez, o que descarta repetições e fórmulas. Isso explica o caso da "neutralidade" em Noite e neblina: não se trata de uma nova prescrição cinematográfica, mas de uma decisão estética sensível ao assunto e ao momento histórico. Nesse sentido, ela é virtualmente irrepetível. 
Martin Heidegger, aluno de Husserl, buscou demonstrar um novo método fenomenológico. Depois de Sein und Zeit (Ser e tempo) ${ }^{6}$, sua filosofia promove promove uma nova abertura com a aplicação do método fenomenológico a fenomenológico a novas regiões: a linguagem, a técnica, a arte. A origem da origem da obra de arte, preparado em 1935-1936, e publicado pela primeira primeira vez como livro em 1950, é um exemplo. Nesse texto, Heidegger concebe a obra de arte como um acontecimento da verdade. Mas, para os nossos propósitos, vale sobretudo sua caracterização da obra em primeiro lugar como "coisa". A categoria da coisa está o tempo todo à espreita da categoria de obra, como se a recordasse de uma dívida. Antes de a obra ser obra, a coisa cumpre um papel decisivo em qualquer fenomenologia, considerando que, no caso da arte, sua concretude impõe-se a despeito das palavras que atribuímos a elas. Sobre o caráter de coisa na obra de arte, Heidegger diz:

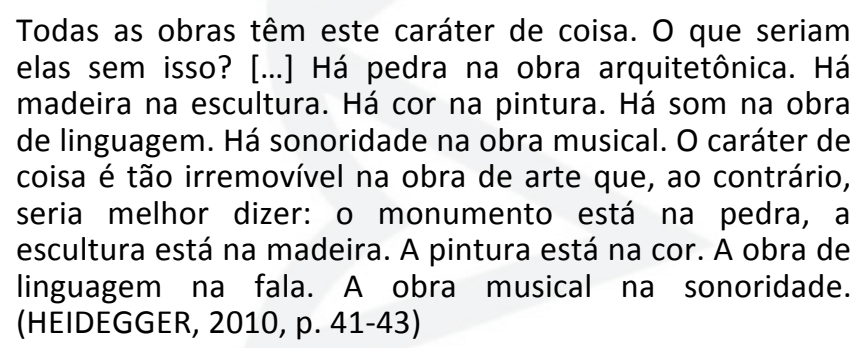

Desse modo, o método fenomenológico possibilita uma expansão das possibilidades de leitura da arte: não se trata mais de uma questão de beleza ou autoria. Em contrapartida, isso garante a dignidade da experiência com qualquer coisa, independentemente do seu eventual status de arte. O mesmo vale para as imagens: não há como hierarquizá-las de acordo com a categoria do "artístico". Ou melhor: isso em nada contribui para a compreensão da experiência que temos com elas.

\footnotetext{
${ }^{6}$ Em sua primeira grande obra inacabada, Sein und Zeit (Ser e tempo, 2006), Heidegger aplica a fenomenologia à ontologia, reestabelecendo uma diferença fundamental entre o ente (aquilo que é) e o próprio ser. Em suma, não se pode falar do ser da mesma maneira como se fala dos entes. Por isso, Heidegger utilizada o termo ser-aí (Dasein) e não substanciações como "ser humano", "homem" etc. Há também um esforço para esclarecer a anterioridade de certos modos do ser-aí em relação aos constructos tradicionais da metafísica.
} 
Nesse sentido, a fenomenologia oferece um poderoso meio de interpretação de acontecimentos que não se conformam simplesmente ao "estético". O filme de Resnais é um exemplo: o problema da linguagem surge entrelaçado a um problema ético e histórico. Pouco importa que as imagens pareçam mais ou menos documentais, ou mais ou menos belas. A decisão pela "neutralidade" nada tem de neutra: ela é uma proposição, uma asserção sobre a dificuldade para reapresentar uma experiência, bem como a inexorável passagem do tempo.

Ademais, a fenomenologia recoloca a questão da banalidade: os mínimos detalhes que a câmera captura devem sua importância à própria ação de olhar. A priori, nada é indigno de atenção; acompanhamos as escolhas de Resnais, enquanto se descortinam diante de nossos olhos aquilo que passaria desapercebido: os arranhões à unha no teto das câmaras de gás. $\mathrm{O}$ desespero e o sofrimento sem tamanho, concentrados no menor dos índices, têm então um efeito explosivo. E assim alguma coisa da experiência dessas vidas possivelmente se transmite.

\section{UMA FENOMENOLOGIA DAS IMAGENS}

Entre os teóricos contemporâneos da arte, o francês Georges Didi-Huberman pertence à linhagem dos fenomenologistas. Em especial, seus estudos sobre as imagens cruzam as barreiras disciplinares erigidas entre estética, política, psicanálise e ciências sociais. Seguindo o método fenomenológico, DidiHuberman toma as imagens em sua imediatidade, independentemente da sua categorização, e articula-as segundo seus regimes de produção e recepção. As imagens não são simplesmente um "em si" ou um "para mim"; mas algo que se mostra a nós, na medida em que vamos ao seu encontro. Nesse sentido, sua fenomenologia das imagens coloca uma questão à disciplina da história da arte:

Com frequência, quando pousamos nosso olhar sobre uma imagem da arte, vem-nos a irrecusável sensação do paradoxo. O que nos atinge imediatamente e sem desvio traz a marca da perturbação, como uma evidência que fosse obscura. Enquanto o que nos parece claro e distinto não é, rapidamente o que percebemos, senão o resultado de um longo desvio - uma mediação, um uso das palavras. (DIDI-HUBERMAN, 2013, p. 9) 
Revela-se assim um conflito permanente no nosso falar sobre as imagens, ou entre o estranhamento que elas provocam como aparições e nossa tentativa de conferir-Ihes algum sentido inteligível. Em suma, para o historiador, crítico ou observador, há permanentemente um jogo entre o visível e o dizível, ou entre o fenomênico e o lógico. A fenomenologia reconhece a inesgotabilidade desse jogo e, por isso, não prescreve de antemão como se deveria falar sobre as imagens. Ela apenas estabelece um princípio de incerteza, constantemente rememorado, de onde é possível partir na busca por uma descrição fiel a cada ocasião, não só àquilo que aparece, mas também a quem aparece e a quem se endereça a descrição.

Nesses termos, as imagens dão acesso a mais do que aquilo que elas representam. Dito de outro modo, elas dão a ver mais do que os olhos enxergam. Elas permitem que imaginemos por quê, como e por quem foram produzidas. Desse modo, aproximam-nos do que é outro, do que está distante no tempo e no espaço; ligam-nos a outras vidas. Esse paradoxo é explorado por Didi-Huberman no seu estudo sobre quatro fotografias produzidas em agosto de 1944 por um grupo de judeus aprisionados em Auschwitz: Images malgré tout (Imagens apesar de tudo) (DIDI-HUBERMAN, 2004).

Para o autor, trata-se de imagens surgidas na união de duas impossibilidades: o desaparecimento da testemunha e a irrepresentabilidade do testemunho (Ibid., p. 22). Também em muitos outros sentidos, a fotografia do massacre parecia impossível: não apenas por conta da camuflagem, do isolamento, da extensão e complexidade do campo de concentração, mas também pelo caráter inimaginável do acontecimento.

Arrancar uma imagem disso, apesar disso? Sim. Custasse o que custasse, haveria de se dar forma a esse inimaginável. As possibilidades de fuga de Auschwitz eram tão escassas que a simples emissão de uma imagem ou de uma informação - um plano, figuras, nomes - se convertia em uma urgência, um dos últimos gestos da humanidade. (Ibid., p. 28, tradução nossa)

Em jogo está uma ação "contra tudo que é inimaginável". Isto é: a captura de uma imagem do Holocausto volta-se contra a sua própria suposta 
irrepresentabilidade. Nesse sentido, é um gesto de coragem, pois o que se quer com essas "máquinas experimentais de uma desaparição generalizada" é apagar toda e qualquer evidência da existência dos judeus; não bastava matáIos (DIDI-HUBERMAN, 2004, p. 37-40).

De fato, "o esquecimento do extermínio faz parte do extermínio". Os nazistas acreditavam, sem dúvida, que haviam tornado os judeus invisíveis e sua própria destruição invisível. [...] Mas a "razão na história" sofreu ainda assim uma refutação - por menor que seja, dispersa, inconsciente ou muito desesperada - de alguns fatos únicos que são, então, a coisa mais preciosa que existe para a memória: sua possibilidade de imaginar. Os arquivos da Shoah definem sem dúvida um território incompleto, de sobrevivência e fragmentário; mas esse território, é claro, existe. (Ibid., p. 43, tradução nossa)

Apoiado na fenomenologia, Didi-Huberman ilumina com esse caso a relação imbricada entre história, representação e política. Trata-se simultaneamente de um documento, um produto de interesse estético e uma ação de resistência. 0 valor dessas imagens não se limita a um dos campos de investigação: elas atravessam as fronteiras entre o forense, o artístico e o social.

Isso tudo com apenas quatro fotografias: duas muito similares entre si, uma "mal dirigida" ao seu assunto, e uma que se volta para o alto, registrando nada além do céu e de uma árvore. Elas possuem, no entanto, uma "eminente força epidêmica" (Ibid., p. 44, tradução nossa) e abrem as diversas dimensões do acontecimento histórico, dando acesso a uma experiência singular. No limite, elas comprovam a permanente possibilidade da experiência e da sua narração "apesar de tudo". Para Didi-Huberman, as quatro fotografias lembram-nos que o produzir imagens redime o nosso poder de imaginar, mesmo dentro do "inferno". 

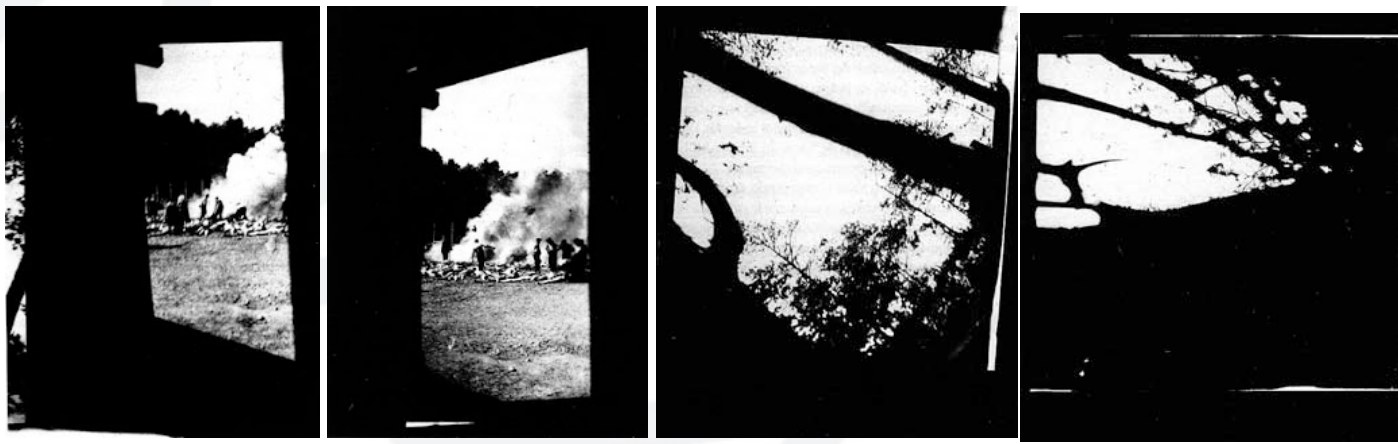

Figuras 6 a 8: Anônimo (membro do Sonderkommando de Auschwitz, provavelmente Alberto Errera, dito "Alex"). Cremação de corpos gazeados em fossas de incineração ao ar livre, diante do Crematório V de Auschwitz, agosto de 1944 Fonte: Museu de Estado Auschwitz-Birkenau (negativos n² 277-278, 282, 283).

A segunda fotografia convida a mais uma investigação. Vemos, através de uma porta, homens e cadáveres à luz do sol, enquanto sobe a fumaça das fossas de incineração contra o plano escuro da vegetação. Um homem sem camisa caminha, pé ante pé, tortuosamente, entre os corpos nus. Está a trabalho. Há um certo prosaísmo na atitude do grupo à direita, como se aguardassem mais instruções. $O$ tom é de normalidade, considerando que o excepcional aqui é o número excessivo de corpos. A circunstância do trabalho ao ar livre, não obstante, enseja o registro do extermínio.

A fotografia é feita dentro de uma câmara de gás - "[t]errível paradoxo este da câmara obscura" (DIDI-HUBERMAN, 2004, p. 29, tradução nossa). Protegendose, o fotógrafo permanece recuado na penumbra. Esta é registrada como região escura ao redor da imagem, formando uma espécie de moldura. DidiHuberman compara então a imagem original com sua versão reenquadrada, sem essa moldura negra. Há, reconhece, uma vontade "boa e inconsciente" de aproximação, "purificando a substância figurada do seu peso não documental" (Ibid., p. 61-63, tradução nossa). Mas o recorte é fatal para a imagem. Com ele "se comete uma manipulação ao mesmo tempo formal, histórica, ética e ontológica" (Ibid., p. 63, tradução nossa). Pois

A massa negra que rodeia a visão dos cadáveres e das fossas onde nada é visível proporciona, na realidade, uma marca visual tão preciosa quanto todo o resto da superfície revelada. [...] Essa massa negra nos proporciona 
a situação ela mesma, o espaço onde é possível a condição de existência das próprias fotografias. Suprimir a "zona de sombra" (a massa visual) em proveito da "informação" luminosa (o atestado visual) é, ademais, fazer com Alex ${ }^{7}$ pudesse ter tirado as fotos, tranquilamente, ao ar livre. É quase insultar o perigo que correu e sua astúcia como resistente. Ao enquadrar de novo essas imagens acreditaram, sem dúvida, estar preservando o documento (o resultado visível, a informação clara). Mas suprimiam delas a fenomenologia, tudo o que faz delas um acontecimento (um processo, um trabalho, um corpo a corpo). (DIDI-HUBERMAN, 2004, p. 63-64, tradução nossa)
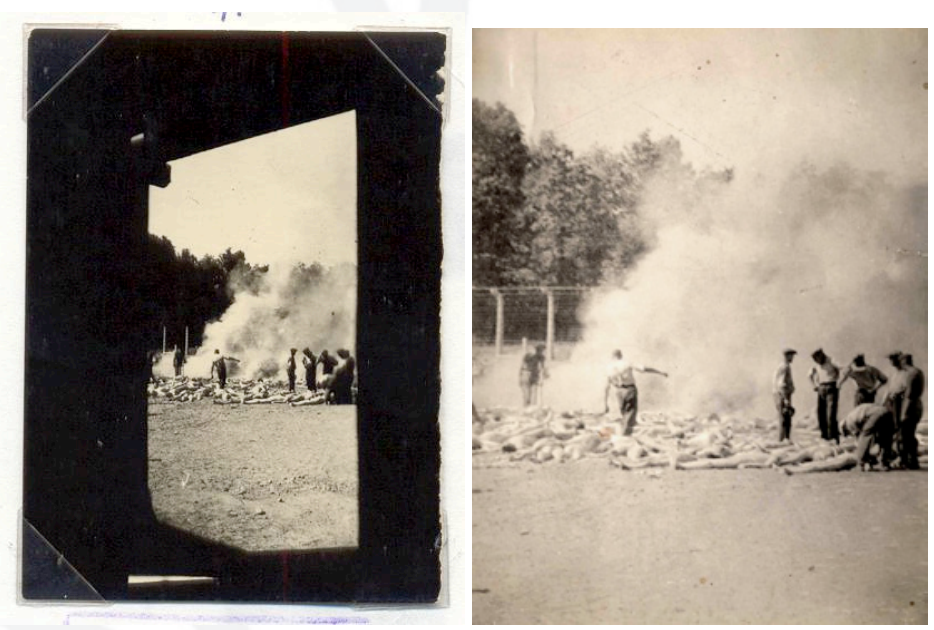

Figuras 9 e 10: Anônimo (membro do Sonderkommando de Auschwitz, provavelmente Alberto Errera, dito "Alex"), agosto de 1944, Fonte: Museu de Estado Auschwitz-Birkenau (negativo n 278 e versão editada).

Com essas palavras, o fenomenólogo reabre uma discussão sobre método e interpretação. Não se trata somente de o que vemos, mas fundamentalmente de como o vemos. Aquilo que nos aparece o faz de determinada maneira, e, nesse sentido, se transformamos a sua maneira de aparecer, transformamonos radicalmente. Isso implica "uma difícil ética da imagem" (Ibid., p. 67, tradução nossa): não há uma visão correta ou mais correta da imagem. Importa então menos uma visão que uma renovação do ver: na comparação acima, o recorte, não obstante inadequado, ajuda a retornar para a imagem original, tendo mais apreço pela massa não informativa. Revela-se novamente

\footnotetext{
${ }^{7}$ Judeu grego não identificado, a quem se atribui a autoria das fotografias (DIDI-HUBERMAN, 2004, p. 29).
} 
o poder dessa imagem com um todo coeso, tensionado internamente entre o visível e o invisível.

A essa "força epidêmica" em questão corresponde, como sugerido por DidiHuberman, uma atitude diante dos fatos históricos, tanto da parte do produtor quanto do receptor da imagem. Uma tal abordagem fenomenológica abre, portanto, um canal de comunicação entre o passado e o presente e constitui ela mesma um método histórico válido. A imagem não apenas dá testemunho - "o olho da história" -, mas também inaugura "um momento de suspense visual" - está "no olho da história", como no olho de um furacão (DIDIHUBERMAN, 2004, p. 67). Em suma, o ver fenomenológico promove um outro modo de experimentar o tempo, entendendo que mesmo uma imagem simples - "inadequada, mas necessária, imprecisa, mas verdadeira" (Ibid., p. 67, tradução nossa) - nos coloca diante do "drama" da história humana e da imagem humana como tal (Ibid., p. 69).

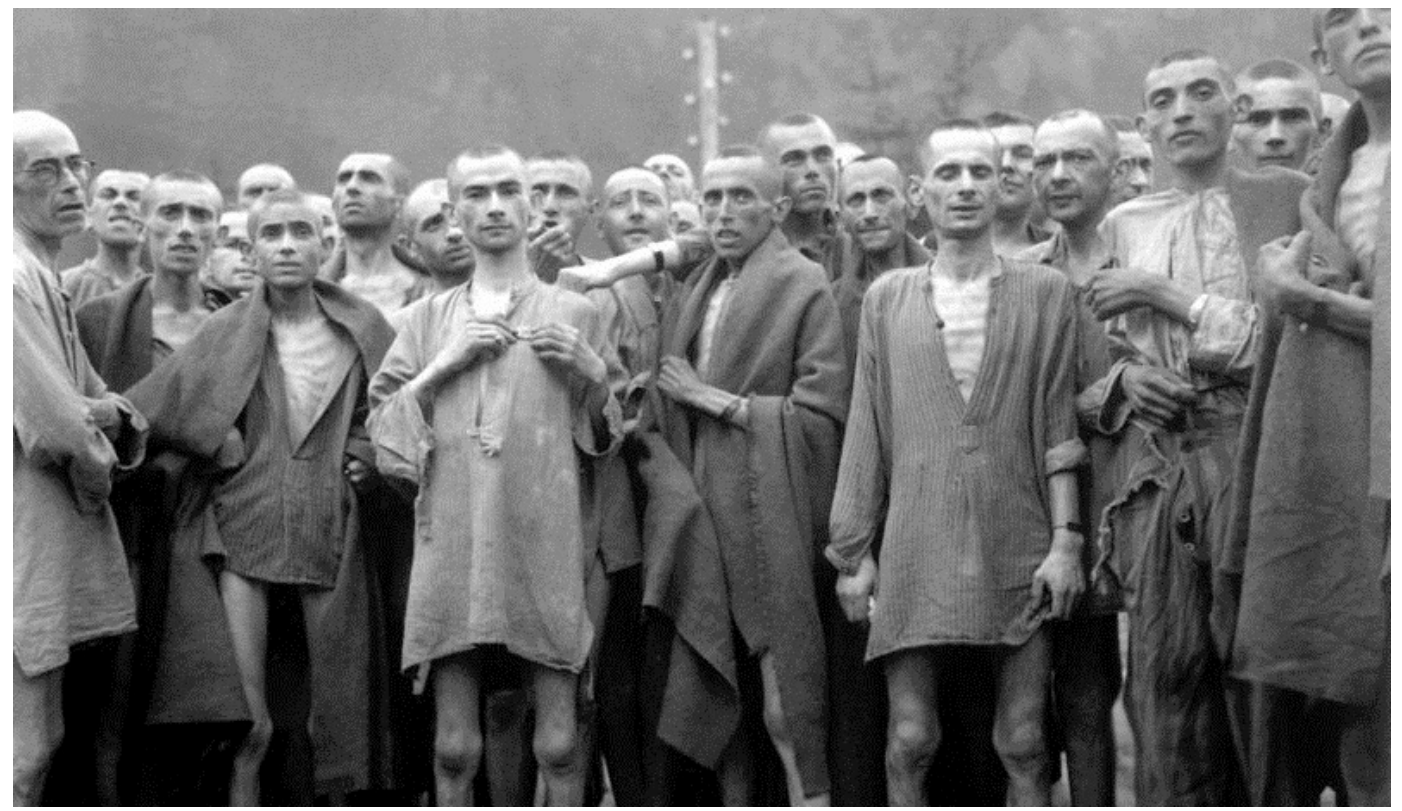

Figura 11: Still do filme. Fonte: Nuit et brouillard (Noite e neblina), 1955. 


\section{CONSIDERAÇÕES FINAIS}

Naturalmente, há uma codependência entre como as coisas são e como as vemos - essa é a correção que tem de ser feita em relação à hipótese inicial do texto. De acordo com o método fenomenológico, a banalização é ao mesmo tempo das imagens e da nossa maneira de vê-las. Se compreendemos corretamente o desenvolvimento do método fenomenológico realizado por Georges Didi-Huberman, isso significa que é impossível separar as imagens da nossa faculdade de imaginar. E que, portanto, toda imagem, quando verdadeiramente observada, aponta para uma possível saída para a atual crise de falta de sentido, a despeito de o que ela é ou representa.

Por tudo que foi dito, trata-se do exercício de ver mesmo onde aparentemente nada há para ver. Esse é o exercício empreendido por Alain Resnais depois da guerra. Por um lado, ele procura capturar uma experiência perdida; por outro, experimenta uma nova maneira de narrar essa impossibilidade. 0 resultado é uma nova experiência de natureza artística, política, ética. O filme não se interpõe entre o espectador e o assunto; ele deixa entrever a tamanha fenda que nos separa das vítimas. Como experiência, no entanto, ela é única, o que torna relativamente infrutíferas as prescrições de neutralidade.

Como Deleuze nos mostra em seu Cinema: imagem tempo, Resnais ao tentar tentar realizar uma representação do irrepresentável, do abjeto pensamento pensamento nazista sobre como gerenciar um extermínio, estabelece uma uma eficaz estratégia de desmerecimento desses atos. Pois não é nos proibindo de imaginar que expressamos melhor seu horror. Não podemos podemos exigir que se interrompam o fluxo de associações, de reflexões que reflexões que as lacunas deixadas por imagens esparsas provocam. O processo processo de representação das imagens nos convida à sua montagem associativa em busca de sentido de reconstituição desses traumas. Um sentido sentido perdido que pode ser entrevisto nas lacunas deixadas pela irrepresentabilidade de gestos tão desmedidos e hostis. É dessa forma que Nuit et brouillard concede traços, rastros e imagens de um tempo 
genocidário: como indícios de imagens de como o homem mesmo arruinou-se arruinou-se diante do seu semelhante (GOMES, 2016).

Logo, a discussão que se impõe doravante é a dos métodos da arte e da crítica de arte. Como procuramos demonstrar, o método fenomenológico não é estritamente estético, mas, partindo de evidências concretas, pode constituir uma ciência histórica e social. Isso supera em muito as intenções de Edmund Husserl. Hoje, o método por ele iniciado tem o poder de contornar os obstáculos impostos pela longa tradição ocidental de separar os saberes e os fazeres de acordo com seus objetos de estudo (subject matter). Nesse sentido, as imagens não são assunto exclusivo nem da arte nem da política.

Ademais, por sua relação imbricada com a maneira como são vistas, as imagens nunca são exatamente neutras, nem mesmo as imagens técnicas como as fotográficas. Imagens são algo com o qual se opera, dando-lhes novos sentidos. Essas operações, por sua vez, são sensíveis à passagem do tempo e à eclosão de novas experiências. Logo, é de se esperar que o mesmo recurso narrativo ganhe significados diferentes a depender dos diferentes contextos de uso.

Por fim, a crise da experiência a qual aludimos merece ainda mais atenção. Assim como Walter Benjamin nos anos 1930, é urgente que conceituemos nossa dificuldade crescente para falar dos fenômenos da arte e do cotidiano. Essa dificuldade já não tem mais a ver com a guerra e a destruição do legado cultural europeu, mas possivelmente com um esgarçamento da sensibilidade e da imaginação promovido pelos novos meios de comunicação e pela lógica de produção e circulação da indústria cultural. Esse esgarçamento levaria a uma atitude derrisória ou indiferente em relação a tudo que nos cerca, com graves consequências para todas as formas de criação. Assim, a banalização do nosso imaginar estaria profundamente ligada às transformações sociais e políticas. 


\section{REFERÊNCIAS BIBLIOGRÁFICAS}

ARENDT, Hannah. Origens do totalitarismo. Trad. Roberto Raposo. São Paulo: Companhia das Letras, 1989.

Eichmann em Jerusalém: um relato sobre a banalidade do mal. Trad. José Rubens Siqueira. São Paulo: Companhia das Letras, 1999.

BENJAMIN, Walter. Magia e técnica, arte e política: ensaios sobre literatura e história da cultura. 7. ed. Trad. Sérgio Paulo Rouanet. São Paulo: Brasiliense, 1994. (Coleção Obras escolhidas, v. 1.)

DELEUZE, Gilles. A filosofia crítica de Kant. Trad. Germiniano Franco. Lisboa: Edições 70, 2009. (Coleção O saber da filosofia, 3.)

A imagem-tempo. Trad. Eloísa de Araujo Ribeiro. São Paulo: Brasiliense, 2007.

DIDI-HUBERMAN, Georges. Imágenes pese a todo: memoria visual del Holocausto. Trad. Mariana Miracle. Barcelona: Paidós, 2004. (Coleção Biblioteca del presente.)

. Diante da imagem: questão colocada aos fins de uma história da arte. Trad. Paulo Neves. São Paulo: Editora 34, 2013.

FLEISCHER, Alain. L'Art d'Alain Resnais. Paris: Centre Georges Pompidou, 1998.

FREUD, Sigmund. Fixação e traumas - o inconsciente. Conferência XVIII de "Conferências introdutórias sobre a psicanálise" [1933]. In: Edição standard brasileira das obras psicológicas completas de Sigmund Freud, vol. XVI. Rio de Janeiro: Imago, 1976.

GADAMER, Hans-Georg. Hegel - Husserl - Heidegger. Trad. Marco Antônio Casanova. Petrópolis: Vozes, 2012.

HEIDEGGER, Martin. Ser e tempo. Trad. Marcia Sá Cavalcante Schuback. Petrópolis/Bragança Paulista: Vozes; Editora Universitária São Francisco, 2006. (Coleção Pensamento humano.)

. A origem da obra de arte. Trad. Idalina Azevedo e Manuel António de Castro. São Paulo: Edições 70, 2010.

HUSSERL, Edmund. Investigações lógicas: sexta investigação: elementos de uma elucidação fenomenológica do conhecimento. Trad. Željko Loparić e Andréa Maria Altino de Campos Loparić. São Paulo: Abril Cultural, 1980. (Coleção Os pensadores.) 
KANT, Immanuel. Crítica da razão pura. 2. ed. Trad. Valério Rohden e Udo Baldur Moosburger. São Paulo: Abril Cultural, 1983. (Coleção Os pensadores.)

\section{Fontes eletrônicas e sites}

GOMES, Priscyla. O inimaginável em Alain Resnais: Cinema e o testemunho do trauma. Revista Centro, 2016. Disponível em:

<http://revistacentro.org/index.php/resnais/>. Acesso em 20 abr. 2020.

\section{LISTA DE FIGURAS}

Figura 1 - Still do filme Nuit et brouillard.

Figuras 2 e 3 -Stills do filme Nuit et brouillard.

Figura 4 - Still do filme Nuit et brouillard.

Figura 5 - Still do filme Nuit et brouillard.

Figuras 6 a 8 -Anônimo (membro do Sonderkommando de Auschwitz, provavelmente Alberto Errera, dito "Alex"). Cremação de corpos gazeados em fossas de incineração ao ar livre, diante do Crematório $V$ de Auschwitz, agosto de 1944.

Figuras 9 e 10 - Anônimo (membro do Sonderkommando de Auschwitz, provavelmente Alberto Errera, dito "Alex"), agosto de 1944 p. 160

Figura 11 - Still do filme Nuit et brouillard. p. 161 